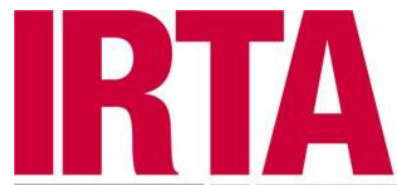

REEGERCA D TECNIOLOGIA

AGROALIMENTARRIES

This document is the Accepted Manuscript version of a Published Work that appeared in final form in Environmental Science \& Technology, copyright $(\subset)$ American Chemical Society after peer review and technical editing by the publisher.

To access the final edited and published work see:

http://dx.doi.org/10.1021/es3045423 


\section{Biodiversity impacts from salinity increase in a 2 coastal wetland}

Maria José Amores ${ }^{1}$, Francesca Verones ${ }^{2}$, Catherine Raptis ${ }^{2}$, Ronnie Juraske ${ }^{2}$, Stephan Pfister ${ }^{2}$, Franziska Stoessel $^{2}$, Assumpció Antón ${ }^{1,3}$, Francesc Castells ${ }^{1}$, Stefanie Hellweg ${ }^{2}$

${ }^{1}$ Universitat Rovira i Virgili, Departament d'Enginyeria Química, 26 Avda Països Catalans, Tarragona, Spain 43007.

${ }^{2}$ ETH Zurich, Institute of Environmental Engineering, Schafmattstrasse 6, 8093 Zurich, Switzerland.

${ }^{3}$ Institute for Food and Agricultural Research and Technology (IRTA), S/N carretera de Cabrils, Cabrils, Barcelona, Spain 8348.

*Corresponding author e-mail: mariajose.amores@urv.cat; phone: +34 977558553

Abstract

A Life Cycle Impact Assessment (LCIA) method was developed to evaluate the environmental impacts associated with salinity on biodiversity in a Spanish coastal wetland. The developed characterization factor consists of a fate and an effect factor and equals $3.16 \times 10^{-1} \pm 1.84 \times 10^{-}$ ${ }^{1} \mathrm{PAF} \cdot \mathrm{m}^{3} \cdot \mathrm{yr} \cdot \mathrm{m}^{-3}\left(\mathrm{PAF}\right.$ : Potentially Affected Fraction of species) indicating a "potential loss of $0.32 \mathrm{~m}^{3}$ ecosystem" for a water consumption rate of $1 \mathrm{~m}^{3} \mathrm{yr}^{-1}$. As a result of groundwater consumption with a rate of $1 \mathrm{~m}^{3}$ per year means that the PAF in the lost cube meter ecosystem is equal to 0.05 which has been proposed as the maximum tolerable effect to keep the ecosystem intact. The fate factor was calculated from seasonal water balances of the wetland Albufera de Adra. The effect factor was obtained from the fitted curve of the potentially affected fraction of native wetland species due to salinity and can be applied to other wetlands with similar species composition. In order to test the applicability of the characterization factor, an assessment of water consumption of greenhouse crops in the area was conducted as a case study. Results converted into ecosystem quality damage using the ReCiPe method were compared to other categories. While tomatoes are responsible for up to $30 \%$ of 


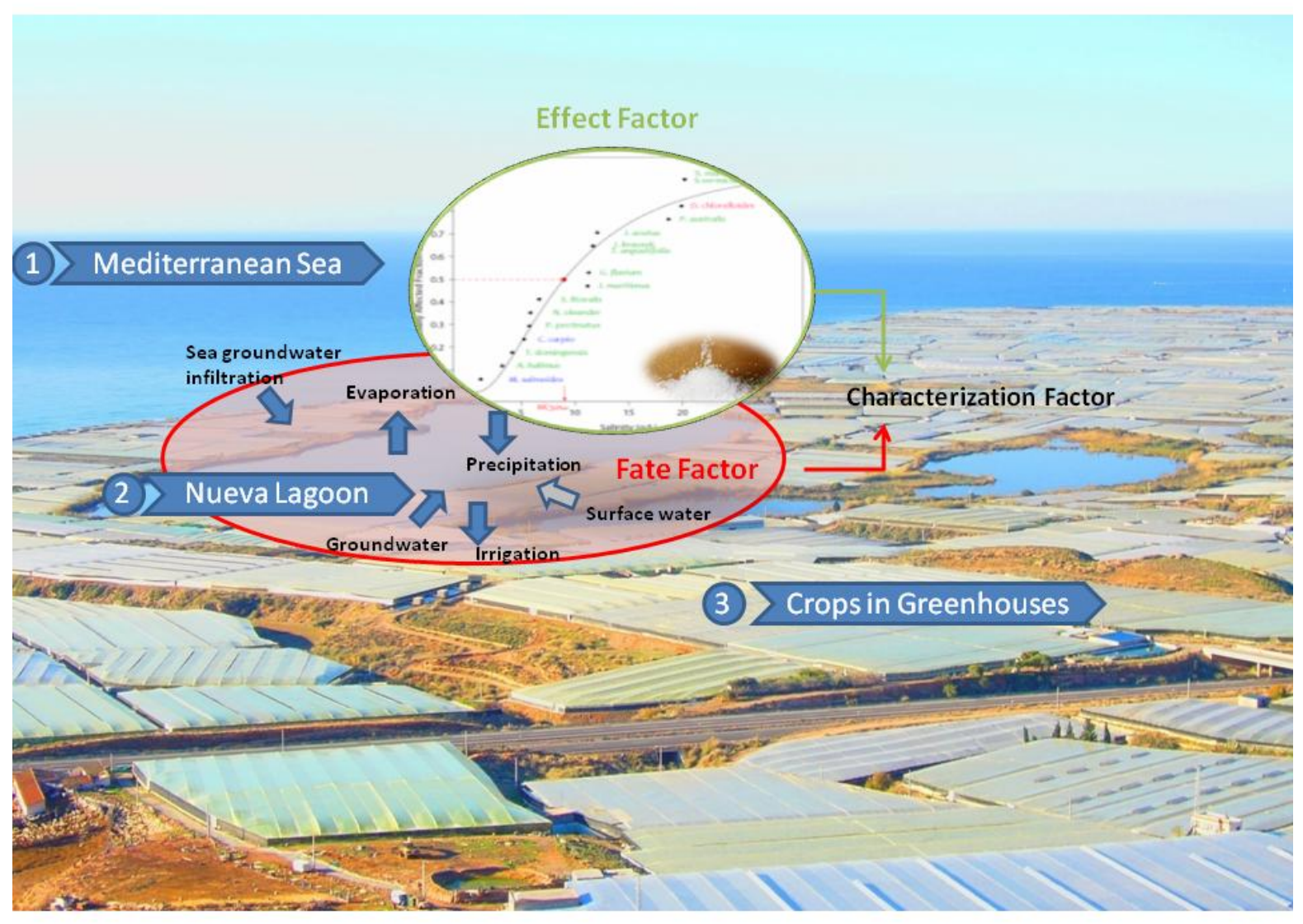

\section{Introduction}

In 2006 the Food and Agricultural Organization of the United Nations (FAO) estimated the global water withdrawals to be $3,830 \mathrm{~km}^{3} \cdot \mathrm{yr}^{-1}$, of which $70 \%$ was used for agriculture. ${ }^{1}$ Additionally, water availability and use related to agricultural production are faced with important challenges such as growing population, climate change and changing dietary patterns. It is thus fundamental to assess impacts and changes in agriculture, in order to respond to challenges in the near future. Wetlands are important and vulnerable ecosystems. More than $50 \%$ of all wetlands worldwide were destroyed during the twentieth century, more than $60 \%$ in Spain and Greece, and more than $70 \%$ in Italy $^{2}$, mostly due to agricultural drainage. ${ }^{3}$ During the last decades, the use of greenhouses instead of traditional farming systems has often been accompanied by additional groundwater withdrawal for 
irrigation. ${ }^{4}$ In coastal areas, over-pumping of aquifers leads to sea water intrusions, thus increasing the salinity in aquifers. At the same time, coastal wetlands, where fresh water and salt water are often mixed, are among the most productive, valuable, and yet most threatened ecosystems in the world. ${ }^{5}$ Coastal wetlands in arid and semi-arid zones experience periods of increasing salinity as a consequence of high evaporative conditions, variability of inflows, their proximity to the sea but also due to impacts of human pressures, ${ }^{6}$ such as overpumping of aquifers. Due to the inflow of salty water, coastal wetlands might experience an increase in salinity, which could potentially be detrimental for the wetland's specific ecological system.

With an increasing awareness of the value and importance of wetlands, fostered by the Ramsar Convention, ${ }^{7}$ numerous coastal wetlands have been designated as wetlands of international importance. Still, environmental impacts due to agricultural practices and dependencies upon wetlands are becoming increasingly significant. ${ }^{8}$ Hence, balancing wetland conservation and wise water use, as well as assessing the prevalent impacts is important for the preservation of the remaining wetlands.

Life Cycle Assessment (LCA) is a method for evaluating the total environmental impact throughout the life cycle of a product or process. ${ }^{9}$ The ISO 14044 standard defines Life Cycle Impact Assessment (LCIA) as the phase of LCA aimed at understanding and evaluating the magnitude and significance of the potential environmental impacts of a product system with the purpose of interpreting the life cycle emissions and resource consumption inventory in terms of indicators for the three Areas of Protection (resources, human health, ecosystem quality). ${ }^{10}$ Several methods have been developed for assessing damages from water use on ecosystems, such as the decrease of terrestrial biodiversity due to freshwater consumption, ${ }^{11}$ the disappearance of terrestrial plant species due to a change in extraction of groundwater, ${ }^{12}$ and the effects on freshwater fish species from water consumption in rivers. ${ }^{13} \mathrm{We}$ understand water consumption in this case study as general water consumption in the wetland (evapotranspiration, product integration, and discharge into the sea or into areas outside the wetland). Recently, a case study dealing with the effects of changes in water temperature and salinity on freshwater molluscs in the river Rhine has been published. ${ }^{14}$ For wetlands in particular, a case study in the coastal arid area of Peru concerning the local plant biodiversity impacts of agricultural water use 
67 has been published. ${ }^{15}$ However, so far no LCIA methodology has taken into account salinity impacts in coastal wetlands.

In order to develop a methodology for salinity impacts, we selected a coastal wetland in Spain called "Albufera de Adra" as an exploratory case study in order to learn (since water-related impacts are quite complex) how to include the impacts from salinity increases due to water consumption. It is located in a semi-arid region in Almería (South-East of Spain), where agricultural activities require substantial irrigation and areas with native vegetation and fauna are restricted to small patches and wetlands. ${ }^{16}$ The aims of this study were (a) to develop a characterization factor (CF) in terms of potentially affected fraction of species (PAF) ${ }^{17}$ for salinity impacts based on a new effect factor and a locally specific new fate factor, and (b) to apply it to a local case study and compare the impact of salinity with commonly used ecosystem quality impact categories.

\section{Materials and Methods}

\section{Description of the wetland Albufera de Adra}

The case study area is located in a semi-arid and mountainous area of South-Eastern Spain, in the province of Almería (N36 45' 16" / W 2 $2^{\circ} 57^{\prime}$ 0' '). Albufera de Adra contains two lagoons which together occupy 36.4 ha. Nueva lagoon is situated closer to the sea than Honda lagoon. The wetland is located at the south-eastern edge of the Adra River Delta ${ }^{18}$ area close to the Mediterranean sea (Figure 1). Only Honda lagoon is recharged with surface water (ephemeral streams) while Nueva lagoon is predominantly fed by groundwater. ${ }^{4}$ From 2003 to 2010, modifications in the surrounding agricultural practices led to differences in the hydrological dynamics in both lagoons. ${ }^{4,19}$ Specifically, an extension of irrigated areas and more efficient irrigation techniques have resulted in a reduced natural and irrigation return-flow to the aquifer. Consequently, the electrical conductivity (as proxy for salinity) $)^{20}$ in Nueva lagoon has increased from 6 to $13 \mathrm{mS} \cdot \mathrm{cm}^{-1}$ due to an increase in sea water intrusion ${ }^{4}$, while in the Honda Lagoon the conductivity has decreased from 6 to $1 \mathrm{mS} \cdot \mathrm{cm}^{-1}$ due to an increase in surface water return flow. 
Albufera de Adra is protected as a nature reserve by the Andalusian Autonomous Government and additionally classified as a wetland of international importance under the Ramsar convention. It harbors a large variety of fauna and flora like plants, fishes and algae and is especially important for waterfowl and autochthonous ichthyofauna. ${ }^{4}$ In this study we focused on plants, fishes, algae and a crustacean.

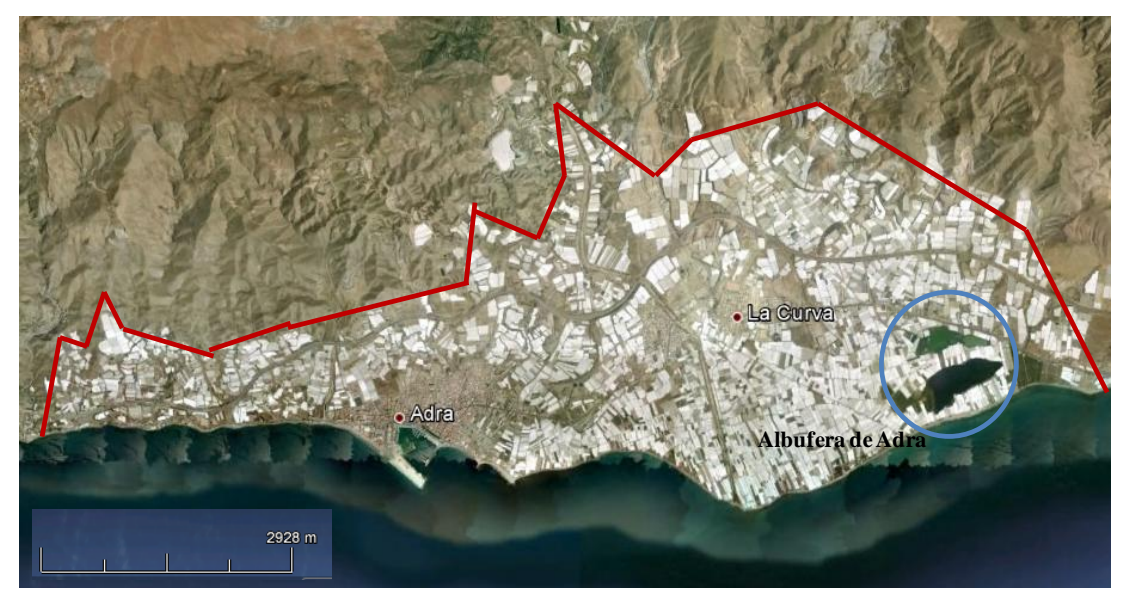

Figure 1: Albufera de Adra (Spain) composed by the larger, coastal Nueva Lagoon and inland Honda Lagoon enclosed in the blue circle. The red line delimits the agricultural area of the study which consists of 899.2 ha $^{21}$ of greenhouses area (white areas). The main economic activity in that area is protected horticulture. ${ }^{22-24}\left(\right.$ Source Google Earth $\left.^{25}\right)$.

\section{Developing the Characterization Factor}

As commonly done in LCIA, Characterization Factors (CF, Equation 1) are calculated as the product of a Fate Factor (FF, Equation 2) and an Effect Factor (EF, Equation 9). The FF models the salinity increase in the wetland due to increased water consumption rate (in $\mathrm{g} \cdot \mathrm{l}^{-1} \cdot \mathrm{m}^{3} \cdot \mathrm{yr} \cdot \mathrm{m}^{-3}$ ) and the EF relates an ecological damage to the increased salinity measured as Potentially Affected Fraction (PAF) of species (in PAF $1 \cdot \mathrm{g}^{-1}$ ). The units from the characterization factor are based on $\mathrm{g} / \mathrm{l}$ which comes from salinity, $\mathrm{m}^{3}$ in numerator comes from the units of Nueva volume, the period time is for one year ( 9 wet months, 3 dry months) and the $\mathrm{m}^{3}$ in denominator comes from $\mathrm{ET}_{\text {crop. }}$ The $\mathrm{CF}$ for the salinity impact in this coastal wetland is therefore defined as the change in PAF of species due to a change in groundwater consumption, which is affecting the salinity content via altered amounts of groundwater and seawater infiltration into the wetland. This can be translated into the effect per $\mathrm{m}^{3}$ of water consumed. 
117 The uncertainties from FF and EF were propagated with Monte Carlo simulation to quantify the 95\% 118 confidence interval of the characterization factor. The assessment was performed with the probabilistic 119 risk assessment simulation software @ risk, version 5.0. ${ }^{26}$ Normal distributions were applied for the FF and EF. The sampling method applied was Latin Hypercube and the number of iterations was 10,000.

Fate Factor. The FF was developed for the Nueva Lagoon since it is closer to the sea and thus affected by sea water intrusions. Moreover, recharge to the wetland from the Adra River Delta aquifer is predominant in the Nueva lagoon, while Honda is mainly fed by surface water. ${ }^{4}$ The FF was based on a salt and a water balance, and we split each up into wet (X) and dry (Y) months, since there is a natural seasonal cycle of salinity. According to Rodriguez et al. ${ }^{4}$ there are 3 dry months (June, July, August) with almost no precipitation and 9 wet months. Due to the precipitation in the wet months, the salinity in the wetland decreases, since freshwater leads to a dilution and an exfiltration of saline water. Salinity increases during the dry period, when evaporation and saline water infiltration increase the salt concentration. Monthly water and salt balances were calculated for 1983, 2003 and 2008, respectively. For the FF calculation (Equation 2) the monthly results were aggregated to yearly values.

$F F=\frac{\Delta F G W}{\Delta \mathrm{ETcrop}} \frac{\Delta C_{N} \cdot V_{N}}{\Delta F G W}\left[\mathrm{~g} \cdot \mathrm{l}^{-1} \cdot \mathrm{m}^{3} \cdot \mathrm{yr} \cdot \mathrm{m}^{-3}\right]$

Equation 2

The first ratio defines the net salinity change due to change in freshwater inflow $\left(\Delta \mathrm{C}_{\mathrm{N}} \cdot \mathrm{V}_{\mathrm{N}} / \Delta \mathrm{FGW}\right)$ while the second part is related to the change in fresh groundwater infiltration due to changes in crop water consumption $\left(\Delta \mathrm{FGW} / \Delta \mathrm{ET}_{\text {crop }}\right) . \mathrm{FGW}\left(\mathrm{m}^{3} \cdot \mathrm{yr}^{-1}\right)$ is the total fresh groundwater inflow to Nueva Lagoon in the dry and wet seasons $\left(\mathrm{FGW}_{\mathrm{x}}+\mathrm{FGW}_{\mathrm{y}}\right)$. C symbolizes the salinity, $\mathrm{V}$ the volume of the Nueva lagoon and $\mathrm{ET}_{\text {crop }}$ is crop evapotranspiration. $\Delta$ symbolizes the change between years. We consider water consumption as crop evapotranspiration. There is not runoff because we are considering greenhouse crops and we estimated leaching fraction lost in sea water trough groundwater flows. 

and $20 \%$ surface water. For more details and explanations of the other constant parameters see Table 1.

142 Equation 2 is calculated for three time spans, 1983-2003, 2003-2008 and 1983-2008. We focused on 143 these years because between 2003 and 2008 the salinity constantly increased from 4.5 to $7.5 \mathrm{~g} / \mathrm{l}^{4}$, and 144 changes in irrigation techniques occurred, along with a trend of greenhouse extension out of the delta 145 valley. We took 1983 as a year with a situation as natural as possible in order to compare to 2003 and 2008 since from 1975 until 1983 the salinity remained constant in Albufera de Adra. ${ }^{28}$

Table 1: Constant parameters in Nueva Lagoon for the years 1983, 2003 and 2008. Climatic parameters were provided by Adra weather station ${ }^{29}$ and water bodies, salinities and morphometric characteristics by existing literature. ${ }^{4}$

\begin{tabular}{|c|c|c|c|c|c|c|}
\hline Parameter & Definition & Unit & $\begin{array}{l}\text { Value } \\
1983\end{array}$ & $\begin{array}{l}\text { Value } \\
2003\end{array}$ & $\begin{array}{l}\text { Value } \\
2008\end{array}$ & Comments \\
\hline$X$ & Wet months in a year ${ }^{4}$ & month & 9 & 9 & 9 & $\begin{array}{l}\text { Number of wet months: January, February, } \\
\text { March, April, May, September, October, } \\
\text { November and December }\end{array}$ \\
\hline$Y$ & Dry months in a year ${ }^{4}$ & month & 3 & 3 & 3 & $\begin{array}{l}\text { Number of dry months: June, July and } \\
\text { August. }\end{array}$ \\
\hline$\Delta C_{N, Y}$ & $\begin{array}{l}\text { Change in salinity from } \\
\text { Nueva in dry months }\end{array}$ & $\mathrm{g} / \mathrm{l}$ & 0.6 & 0.6 & 0.6 & $\begin{array}{l}\text { Increase in salinity due to } \\
\text { evapotranspiration and almost no } \\
\text { precipitation assuming steady state in the } \\
\text { individual years. This value was taken as } \\
\text { assumption. }\end{array}$ \\
\hline$\Delta C_{N, X}$ & $\begin{array}{l}\text { Change in salinity from } \\
\text { Nueva in wet months }\end{array}$ & $\mathrm{g} / \mathrm{l}$ & -0.6 & -0.6 & -0.6 & $\begin{array}{l}\text { Decrease in salinity due to higher } \\
\text { precipitation levels and lower } \\
\text { evapotranspiration during the wet months }{ }^{4} \text {. } \\
\text { It is assumed that the salt balance must be } \\
\text { zero in order to get the natural behavior of a } \\
\text { stable situation over the year, so we assume } \\
\text { that } \Delta C_{N 2}=-\Delta C_{N 1} \text { as a simplifying } \\
\text { assumption in steady state although is an } \\
\text { evidence that salinity is increasing over the } \\
\text { years. }\end{array}$ \\
\hline$V_{N}$ & $\begin{array}{l}\text { Volume of Nueva } \\
\text { taking area and depth } \\
\text { from literature }\end{array}$ & $\mathrm{m}^{3}$ & 316,667 & 316,667 & 316,667 & $\begin{array}{l}\text { Assuming the volume as a cone with a } \\
\text { maximum depth of } 3.8 \mathrm{~m} \text { and area of } 25 \text { ha } \\
\text { took from literature. The water level did not } \\
\text { change much between } 2006 \text { and } 2008 \\
\text { according to the Rodriguez et al. }{ }^{4}\end{array}$ \\
\hline$C_{G W}$ & $\begin{array}{l}\text { Salinity of the fresh } \\
\text { groundwater }\end{array}$ & $\mathrm{g} / \mathrm{l}$ & 1.6 & 1.6 & 1.6 & $\begin{array}{l}\text { Considering the salinity of the groundwater } \\
\text { in the Adra River Delta Aquifer from the } \\
\text { literature. }\end{array}$ \\
\hline$C_{\text {Sea }}$ & $\begin{array}{l}\text { Salinity in the } \\
\text { Mediterranean Sea }\end{array}$ & $\mathrm{g} / \mathrm{l}$ & 37.6 & 37.6 & 37.6 & $\begin{array}{l}\text { Assuming an average of the Mediterranean } \\
\text { Sea from literature. }\end{array}$ \\
\hline$C_{N}$ & Salinity in Nuevalagoon & $\mathrm{g} / \mathrm{l}$ & 2.6 & 4.50 & 7.50 & $\begin{array}{l}\text { Salinity averages from } 2003 \text { and } 2008 \\
\text { according to Rodriguez et al. }{ }^{4} \text { using as } \\
\text { conversion } 1 \mathrm{mS}=0.64 \mathrm{~g} \cdot \mathrm{l}^{-1}\end{array}$ \\
\hline$E T_{Y}$ & $\begin{array}{l}\text { Nueva } \\
\text { evapotranspiration in }\end{array}$ & $\mathrm{m}^{3} / \mathrm{month}$ & 59,325 & 39,432 & 41,098 & $\begin{array}{ll}\text { Average evapotranspiration } & \text { from dry } \\
\text { months between } 2003 \text { to } 2008 \text {. The values }\end{array}$ \\
\hline
\end{tabular}




\begin{tabular}{|c|c|c|c|c|c|c|}
\hline & $\begin{array}{l}\text { dry months from } \\
\text { IFAPA weather } \\
\text { station }^{29}\end{array}$ & & & & & were taken from literature per area of $25 \mathrm{ha}$. \\
\hline$E T_{X}$ & $\begin{array}{l}\text { Nueva } \\
\text { evapotranspiration in } \\
\text { wet months from } \\
\text { IFAPA weather } \\
\text { station }^{29}\end{array}$ & $\mathrm{~m}^{3} /$ month & 24,331 & 21,337 & 23,737 & $\begin{array}{l}\text { Average evapotranspiration from wet } \\
\text { months between } 2003 \text { to } 2008 \text {. The values } \\
\text { were taken from literature per area of } 25 \text { ha. }\end{array}$ \\
\hline$P_{Y}$ & $\begin{array}{l}\text { Precipitation in } 3 \\
\text { drymonths }{ }^{29}\end{array}$ & $\mathrm{~m}^{3} / \mathrm{month}$ & 1,308 & 183.3 & 33.3 & $\begin{array}{l}\text { Average precipitation from dry months } \\
\text { between } 2003 \text { to } 2008 \text { considering } 25 \text { ha of } \\
\text { surface. The values were taken from } \\
\text { literature. }\end{array}$ \\
\hline$\overline{P_{X}}$ & $\begin{array}{l}\text { Precipitation in } \\
9 \text { wetmonths }\end{array}$ & $\mathrm{m}^{3} / \mathrm{month}$ & 5,419 & 8,933 & 9,911 & $\begin{array}{l}\text { Average precipitation from wet months } \\
\text { between } 2003 \text { to } 2008 \text { considering } 25 \text { ha of } \\
\text { surface. The values were taken from } \\
\text { literature. }\end{array}$ \\
\hline$E T_{N}$ & $\begin{array}{l}\text { Evapotranspirationfrom } \\
\text { Nueva }^{29}\end{array}$ & $\mathrm{~m}^{3} / \mathrm{month}$ & 33,079 & 25,860 & 28,076 & $\begin{array}{l}\text { Evapotranspiration's average from } 2003 \text { to } \\
2008 \text { taking into account the } 25 \text { ha surface } \\
\text { of the lagoon. }\end{array}$ \\
\hline$P_{N}$ & Precipitation in Nueva ${ }^{29}$ & $\mathrm{~m}^{3} / \mathrm{month}$ & 4,392 & 6,745 & 7,442 & $\begin{array}{l}\text { Precipitation's average from } 2003 \text { to } 2008 \\
\text { taking into account the } 25 \text { ha of surface of } \\
\text { the lagoon. }\end{array}$ \\
\hline$\overline{E T_{\text {crop }}}$ & $\begin{array}{l}\text { Crop } \\
\text { Evapotranspiration }^{30}\end{array}$ & $\mathrm{~m}^{3} /$ month & 146,368 & 306,849 & 320,984 & $\begin{array}{l}\text { Taking into account the harvested areas for } \\
2003 \text { and } 2008 \text { from literature } \\
23\end{array}$ \\
\hline$S W_{Y}$ & $\begin{array}{l}\text { Surface water inflows } \\
\text { in dry }\end{array}$ & $\mathrm{m}^{3} / \mathrm{month}$ & 0 & 0 & 0 & $\begin{array}{l}\text { In all equations } \mathrm{SW}_{\mathrm{Y}} \text { is the surface water } \\
\text { inflows in dry months but we neglected it } \\
\text { since it is irrelevant for the Nueva Lagoon }\end{array}$ \\
\hline$S W_{X}$ & $\begin{array}{l}\text { Surface water inflows } \\
\text { in wet }\end{array}$ & $\mathrm{m}^{3} /$ month & 0 & 0 & 0 & $\begin{array}{l}\text { In all equations } \mathrm{SW}_{\mathrm{X}} \text { is the surface water } \\
\text { inflows in wet months but we neglected it } \\
\text { since it is irrelevant for the Nueva Lagoon }\end{array}$ \\
\hline
\end{tabular}

152 In order to obtain the unknown variables, $\mathrm{FGW}_{\mathrm{Y}}, \mathrm{FGW}_{\mathrm{X}}, \mathrm{SGW}_{\mathrm{Y}}$ and $\mathrm{SGW}_{\mathrm{X}}$, we developed several 153 equations for salt and water balances considering wet (X) and dry (Y) seasons. Equation 3 shows the 154 salt balance for dry months, taking into account fresh groundwater inflows (FGW), subterranean sea 155 water intrusions (SGW, henceforward called sea groundwater inflows) and groundwater outflow $156\left(\mathrm{GW}_{\mathrm{o}}\right)$ from Nueva Lagoon to the neighboring aquifer. Equation 4 shows the salt balance for wet 157 months with inflows from fresh groundwater and sea groundwater, as well as groundwater outflow. 158 Equation 5 is the yearly salt balance, incorporating both dry (Y) and wet (X) months and reflects the 159 steady-state assumption, that the yearly balance is equal to zero. Equations 6,7 and 8 are the water 160 balances for dry (Y) and wet (X) months, respectively, as well as the yearly balance. The difference 161 between evapotranspiration (ET) and precipitation $(\mathrm{P})$ in dry months is greater than or equal to the sum 162 of the respective inflows, which consists of fresh and sea groundwater inflows. Concerning the wet months, Equation 7 shows the difference between evapotranspiration and precipitation being lower 
than or equal to the sum of inflows and the groundwater outflow. To solve the system of equations we assume the algebraic sign in Equation 6 and Equation 7 to be equality instead of inequality. The yearly water balance (Equation 8) is zero due to the steady-state assumption.

\section{Salt Balances}

$\frac{\Delta C_{N 1} \cdot V_{N}}{Y}=S W_{Y} \cdot C_{S W}+F G W_{Y} \cdot C_{G W}+S G W_{Y} \cdot C_{S e a}-G W_{o, y} \cdot C_{N}$

Equation 3

$\frac{\Delta C_{N 2} \cdot V_{N}}{X}=S W_{X} \cdot C_{S W}+F G W_{X} \cdot C_{G W}+S G W_{X} \cdot C_{S e a}-G W_{o, x} \cdot C_{N}$

Equation 4

$0=Y \cdot S W_{Y} \cdot C_{S W}+X \cdot S W_{X} \cdot C_{S W}+Y \cdot F G W_{Y} \cdot C_{G W}+X \cdot F G W_{X} \cdot C_{G W}+Y \cdot S G W_{Y} \cdot C_{S e a}+X \cdot$

$S G W_{X} \cdot C_{S e a}-X \cdot G W_{o, x} \cdot C_{N}-Y \cdot G W_{o, y} \cdot C_{N}$

Equation 5

Water Balances

$E T_{Y}-P_{Y} \geq S W_{Y}+F G W_{Y}+S G W_{Y}-G W_{o, y}$

Equation 6

$E T_{X}-P_{X} \leq S W_{X}+F G W_{X}+S G W_{X}-G W_{o, x}$

Equation 7

$0=-E T_{N} \cdot 12+P_{N} \cdot 12+Y \cdot S W_{Y}+X \cdot S W_{X}+Y \cdot F G W_{Y}+X \cdot F G W_{X}+Y \cdot S G W_{Y}+X \cdot S G W_{X}-$ $X \cdot G W_{o, x}-Y \cdot G W_{o, y}$

$S G \mathrm{~W}_{\mathrm{Y}}\left(\mathrm{m}^{3} \cdot \mathrm{month}^{-1}\right)$ and $\mathrm{SGW} \mathrm{X}\left(\mathrm{m}^{3} \cdot \mathrm{month}^{-1}\right)$ are the sea groundwater inflow into Nueva Lagoon in dry and wet months, respectively and $\mathrm{GW}_{\mathrm{o}, \mathrm{y}}\left(\mathrm{m}^{3} \cdot \mathrm{month}^{-1}\right)$ and $\mathrm{GW}_{\mathrm{O}, \mathrm{x}}\left(\mathrm{m}^{3} \cdot \mathrm{month}^{-1}\right)$ are the groundwater outflow from Nueva Lagoon in the dry and wet months, respectively. The values of the unknown variables of Equations 3 to 8 were obtained with the help of the solver GAMS $\bigodot^{31}$ using non-linear programming through the $\mathrm{BARON}{ }^{31}$ optimizer and the equation system was solved by minimizing the balance error. We established Equation 5 as the objective function which is to be minimized (to get close to zero) in that solver.

A sensitivity analysis was carried out by changing different constant parameters, such as salinities $\left(\mathrm{C}_{\mathrm{N}, 1983,}, \mathrm{C}_{\mathrm{N}, 2003}, \mathrm{C}_{\mathrm{N}, 2008}\right)$, the number of wet $(\mathrm{X})$ and dry $(\mathrm{Y})$ months and the amount of precipitation and evapotranspiration. Several assumptions were made in this section (see Supporting Information, 
sectionS2.1.).The confidence intervals for the FF were calculated by taking into account the maximum and minimum FF from the sensitivity analyses and assuming a normal distribution.

Effect Factor. Data describing the effect of salinity for various endpoints (e.g. survival, growth inhibition) on 18 species (plants, fish, algae and a crustacean) native to the "Albufera de Adra" wetland were collected from literature $\mathrm{r}^{32-48}$ and are shown in the Supporting Information (Table S1). This work focused on the indigenous species and the associated damages only. As is common in LCA, only negative impacts are considered and that potential benefits and changes in species composition are not included.

The use of EC50s from bioassays with different endpoints is the norm in the calculation of effect factors in LCA. A prime example for such practice can be found in USEtox, the LCIA toxicity model recommended by UNEP-SETAC: one of the two ecotoxicity effect factor databases used in this model $^{49}$, explicitly states that the EC50s, employed in the construction of SSDs and subsequently the derivation of EFs, can come from numerous different endpoints. Indeed it would be much more consistent to could construct SSDs based on EC50s describing the exact same effect (e.g. death or growth) of a stressor on an organism. However, in light of the absence of identical endpoints measured in bioassays, in LCIA the aggregation of many different endpoints is preferred over the use of much fewer data in the calculation of the EF.

The $50 \%$ effective concentration (EC50) due to salinity is the concentration where a $50 \%$ reduction in a given endpoint (e.g. growth) is observed compared to the control. EC50s were either calculated by fitting the log-logistic function to the salinity concentration-response plots (see figure S1), or were taken directly from literature.

Species Sensitivity Distribution (SSD) is an ecotoxicological tool that has been employed to calculate effect factors for different impacts (e.g. ecotoxicity, thermal pollution, eutrophication) in life cycle impact assessment. Several studies have been published in literature using SSD to obtain an EF, such as Meent et al. ${ }^{50}$, who proposed a multisubstance potentially affected fraction (msPAF)-based method 
for calculating ecotoxicological effect factors for LCA,Verones et al. ${ }^{51}$, who used SSD to calculate an EF for thermal pollution in freshwater aquatic environments and Struijs et al. ${ }^{52}$, who constructed a field sensitivity distribution of macroinvertebrates in inland waters to derive an EF for eutrophication due to phosphorus.

The SSD for salinity was constructed by fitting the log-normal cumulative distribution function to the EC50s for native species (see Table S1). Equation 9 describes the effect factor $\left(\mathrm{EF}_{\mathrm{Sal}}\right)$, which is the average change in the potentially affected fraction of freshwater aquatic species $(\triangle \mathrm{PAF}$ Sal $)$ due to the change in salinity $(\Delta \mathrm{Sal})$. The effect factor is calculated as the average gradient at the $50 \%$ hazardous concentration $\left(\mathrm{HC}_{50} 0_{\mathrm{Sal}}\right)$, defined as the concentration at which $50 \%$ or more of the species included in the SSD are exposed to concentrations above their EC50 $0^{53}$.

$E F_{\text {Sal }}=\frac{\Delta P A F_{\text {Sal }}}{\Delta S a l}=\frac{0.5}{H C 50_{\text {Sal }}}\left[\mathrm{PAF} \cdot \mathrm{l} \cdot \mathrm{g}^{-1}\right]$

Equation 9

A $95 \%$ confidence interval for the hazardous concentration was estimated by parametric bootstrapping and this uncertainty was propagated to the Effect Factor by taking Equation 9 into account.

Calculation of impact scores. The required amount of consumptive irrigation water (CW, $\mathrm{m}^{3}$ ),resulting from the inventory of input/output data, is expressed by a functional unit (quantified performance of a product system for use as a reference unit). ${ }^{10}$ In our case, the functional unit is a tonne of tomato, pepper, cucumber, zucchini, watermelon, melon, aubergine or green bean harvested in greenhouses close to Albufera de Adra. ${ }^{24}$ The impact score (IS, $\mathrm{m}^{3} \cdot \mathrm{PAF} \cdot \mathrm{yr}$ ) is the product of the CF (Equation 1) and the CW. IS shows the impact of increasing salinity on aquatic species in the Nueva lagoon caused by the use of groundwater for agriculture.

Water consumption was calculated as the average evapotranspiration for the different cultivation periods for each crop following the irrigation crop management practices recommended by the experimental station of Cajamar research institute ${ }^{30}$ to improve the efficiency of agriculture production close to the wetland. 
We considered the area of greenhouses from the municipality of Adra $^{21}$ for the 8 main crops from 26

237 different vegetables that are produced in Almería. Amounts of production from the province of Almería $^{23}$ in 2008 were downscaled to the area around Albufera de Adra.

In order to compare the impact due to water consumption to that of other categories, results were converted to species per year following the recommendations of the ReCiPe method (species density for freshwater, $7.89 \times 10^{-10}$ species $\left.\cdot \mathrm{m}^{-3}\right) .^{54}$

\section{Results and discussion}

Fate Factor. There was fresh groundwater inflow $\left(\mathrm{FGW}_{\mathrm{Y}}\right.$ and $\left.\mathrm{FGW}_{\mathrm{X}}\right)$ from the Adra River Delta (ARD) aquifer in wet and dry seasons in all three years. Sea groundwater inflow occurs in dry months only, while groundwater outflow occurs in wet seasons only. This shows that there is less recharge to the wetland from the aquifer in wet months. We further simplified the groundwater system presented by Rodriguez et al. ${ }^{4}$ by neglecting the blurred transition zone between low and high salinity parts of the aquifer, which is not a subsystem in our model. Since only salinities of the fresh groundwater and the sea water are known we assumed sharply separated sections of fresh and saline groundwater. Also, the location of the brackish-freshwater transition zone in the aquifer fluctuates during the seasons, which we did not take into account (Table 2).

Table 2: Unknown variables in Nueva Lagoon for the years 1983, 2003 and 2008 . The values of the variables are obtained by solving the equation system of Equation 3 to Equation 8 with GAMS. ${ }^{31}$

\begin{tabular}{|c|c|c|c|c|c|c|}
\hline Parameter & Definition & Unit & $\begin{array}{c}\text { Value } \\
1983 \\
\end{array}$ & $\begin{array}{c}\text { Value } \\
2003\end{array}$ & $\begin{array}{l}\text { Value } \\
2008\end{array}$ & Comments \\
\hline$F G W_{Y}$ & $\begin{array}{l}\text { Fresh groundwater } \\
\text { inflow to Nueva } \\
\text { Lagoon in dry months }\end{array}$ & $\mathrm{m}^{3} /$ month & $3.96 \times 10^{+4}$ & $3.92 \times 10^{+4}$ & $3.96 \times 10^{+4}$ & Calculated from Equation 3 to Equation 8 \\
\hline$F G W_{X}$ & $\begin{array}{l}\text { Fresh groundwater } \\
\text { inflow to Nueva } \\
\text { Lagoon in wet months }\end{array}$ & $\mathrm{m}^{3} /$ month & $8.63 \times 10^{+4}$ & $2.65 \times 10^{+4}$ & $2.18 \times 10^{+4}$ & Calculated from Equation 3 to Equation 8 \\
\hline$S G W_{Y}$ & $\begin{array}{l}\text { Sea groundwater } \\
\text { infiltration into Nueva } \\
\text { Lagoon in dry months }\end{array}$ & $\mathrm{m}^{3} / \mathrm{month}$ & 0 & $1.49 \times 10^{+1}$ & 0 & Calculated from Equation 3 to Equation 8 \\
\hline$S G W_{X}$ & $\begin{array}{l}\text { Sea groundwater } \\
\text { infiltration into Nueva } \\
\text { Lagoon in wet months }\end{array}$ & $\mathrm{m}^{3} / \mathrm{month}$ & 0 & 0 & 0 & Calculated from Equation 3 to Equation 8 \\
\hline$G W_{o, y}$ & $\begin{array}{l}\text { Groundwater outflow } \\
\text { from Nueva Lagoon in } \\
\text { the dry months }\end{array}$ & $\mathrm{m}^{3} / \mathrm{month}$ & 0 & 0 & 0 & Calculated from Equation 3 to Equation 8 \\
\hline
\end{tabular}


In dry periods, groundwater from ARD aquifer enters the lagoon. For the years 2003 and 2008 the rate throughout the months of June to August was similar. ${ }^{4}$ During wet periods the wetland and aquifer produce additionally a groundwater outflow to the sea, as has been found previously by Alcalá et al. ${ }^{55}$ Still, the presence of the wetland at the south-eastern edge of the ARD aquifer reduced potential groundwater discharge to the sea because of the high evapotranspiration rates in the surface area of this wetland. ${ }^{56}$

Comparing the three years $(1983,2003,2008)$, the ratio between outflow and inflow from and to the wetland is constantly reduced. In 1983, the outflow was $82 \%$ of the inflow, in 2003 it was $48 \%$ while in 2008 it was only $28 \%$. We suggest as principal FF the one between 2003 and 2008 due to the best quality of the data and the stabilization of crop extension.

Results for the sensitivity analysis are shown in the SI Table S2. The maximum value of the FF occurs between 2008 and 2003 when the wetland salinity is increased by $20 \%$ and the other parameters are kept constant, which gives a $\mathrm{FF}_{2008-2003}$ of $6.72 \mathrm{~g} \cdot \mathrm{l}^{-1} \cdot \mathrm{m}^{3} \cdot \mathrm{yr} \cdot \mathrm{m}^{-3}$. On the other hand, the minimum value of the FF results by decreasing the salinity by $20 \%$ for the period between $2003-1983$ with a FF of $2.50 \times 10^{-1} \mathrm{~g} \cdot 1^{-1} \cdot \mathrm{m}^{3} \cdot \mathrm{yr} \cdot \mathrm{m}^{-3}$. These two extreme scenarios were taken as minimum and maximum for the uncertainty assessment and for establishing the distribution function.

\section{Effect Factor}

Figure 2 shows the species sensitivity distribution (SSD) for salinity, for native species identified in the Nueva lagoon. The log-normal cumulative distribution function was fitted to ordered EC50 values, and the $\mathrm{HC} 50_{\text {Sal }}$ was found to be equal to $8.87 \mathrm{~g} \cdot 1^{-1}$ from the fitted curve. The $95 \%$ confidence interval for the HC50 $0_{\text {Sal }}$ was calculated as $6.29-12.5 \mathrm{~g} \cdot \mathrm{l}^{-1}$. The EF was then found to be $5.64 \times 10^{-2} \mathrm{PAF} \cdot 1 \cdot \mathrm{g}^{-1}$ with a standard error of $\pm 0.76 \times 10^{-2} \mathrm{PAF} \cdot 1 \cdot \mathrm{g}^{-1}$, calculated via propagating the error from the HC50 to the EF. 


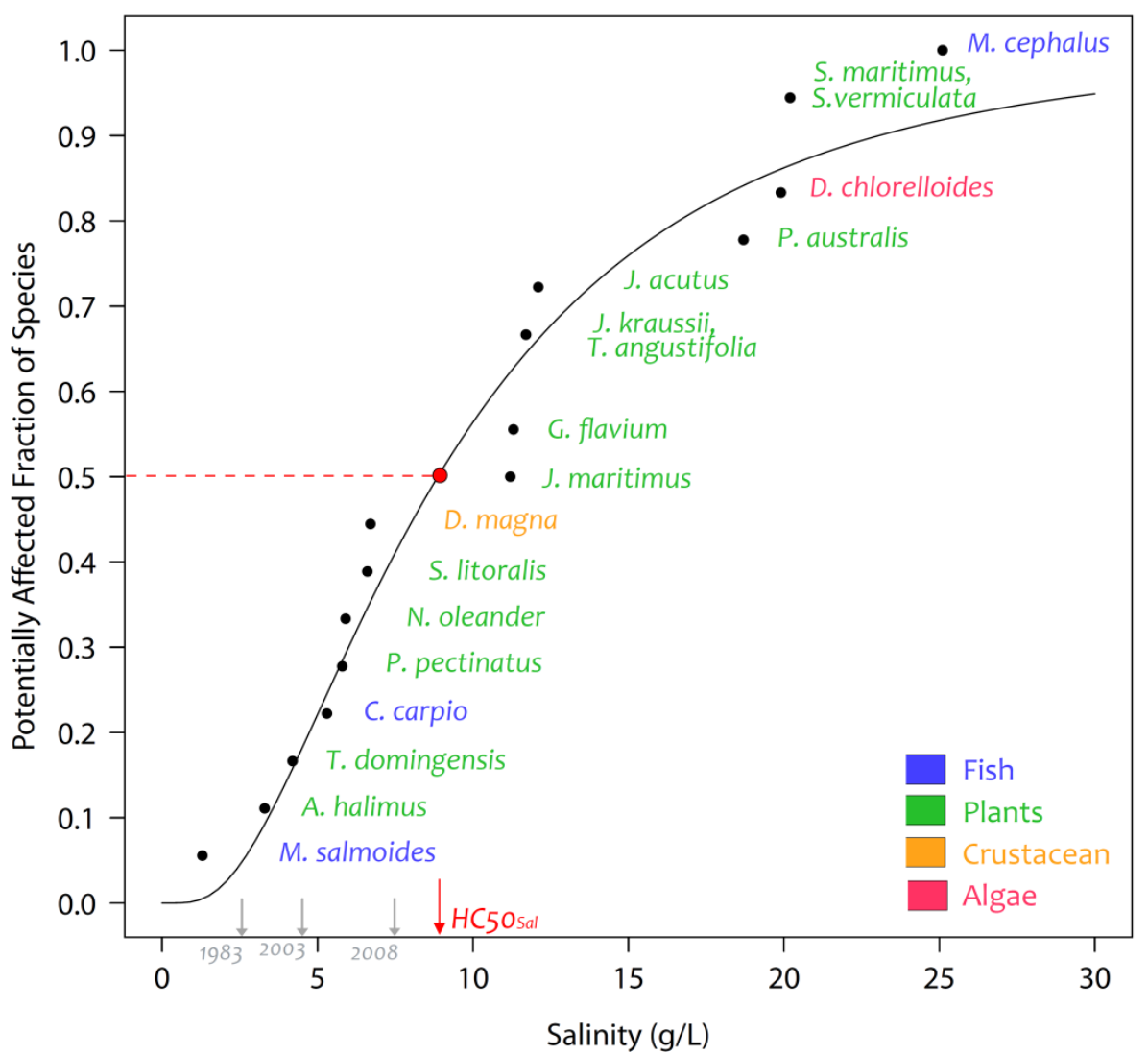

Figure 2:Species Sensitivity Distribution (SSD) for salinity for 18 species native to Nueva Lagoon. The grey arrows indicate the salinity in $1983\left(2.6 \mathrm{~g} \cdot \mathrm{l}^{-1}\right), 2003\left(4.5 \mathrm{~g} \cdot \mathrm{l}^{-1}\right)$ and $2008\left(6.5 \mathrm{~g} \cdot \mathrm{l}^{-1}\right)$.

Salinity in the Nueva Lagoon increased from $4.5 \mathrm{~g} \cdot \mathrm{l}^{-1}$ in 2003 to $7.5 \mathrm{~g} \cdot \mathrm{l}^{-1}$ in 2008 (Table 1), which, according to Figure 2, corresponds to an increase of approximately $20 \%$ of species potentially affected in this period. The absolute number of species estimated to be found in the wetland is $30^{57}$,taking into account plants, fish, algae and crustaceans. The increase in salinity and eutrophication over the past years has already resulted in the disappearance of a specie in Albufera de Adra, namely Scirpus lacustri, which was cited by Losa and Rivas Godo in $1968^{58}$ and Sagredo in $1987^{59}$ but is no longer found in the lagoon today. From Figure 2 we observe that two fish species, $M$. salmoides $(\mathrm{EC} 50=1.3$ $\mathrm{g} \cdot \mathrm{l}^{-1}$ ) and C. carpio $\left(\mathrm{EC} 50=5.3 \mathrm{~g} \cdot \mathrm{1}^{-1}\right)$, are particularly sensitive to salt stress, and another fish species, M. cephalus $\left(\mathrm{EC} 50=25.1 \mathrm{~g} \cdot \mathrm{l}^{-1}\right)$, is the least sensitive of all the native species included in this study. The EC50 of the algae included in the SSD, D. chlorelloides is $19.9 \mathrm{~g} \cdot \mathrm{l}^{-1}$ and is above $H C 50_{\text {sal }}$ but the crustacean, D.magna is located below $\mathrm{HC} 5 \mathrm{O}_{\text {sal }}$ with an EC50of $6.6 \mathrm{~g} \cdot \mathrm{l}^{-1}$. Plants, the most abundant taxonomic group are distributed throughout the SSD, with 5 species lying below $\mathrm{HC}_{5 O_{\text {sal }}}$ and 8 species lying above it. 
Data availability permitted the consideration of 18 species from Nueva Lagoon (13 plants, 3 fish, 1 algae and 1 crustacean) in this work. So, given a total of 30 species reported to be found in the wetland $^{57}$, with these 18 species we cover $60 \%$ of the species in the wetland. The calculated EF could, with some caution, be applied to other wetlands, assuming their native species composition is not entirely dissimilar to the one encountered in Nueva Lagoon.

For instance, Punta Entinas is an endorheic wetland, located in the arid southeast of Spain very close to Albufera de Adra surrounded by Mediterranean ecosystems. Both wetlands, Nueva Lagoon and Punta Entinas (focus on salt marsh and marshland) have species in common, for instance A. halimus, $S$. vermiculata,S. maritimus, J. maritimus, J. acutus, P. australis, $N$. oleander, P. pectinatus and D. chlorelloides $^{57}$ ), amounting to $50 \%$ of the species included in the EF for Albufera de Adra. Therefore, we might consider the EF to be applicable for the marshland of Punta Entinas.

\section{Characterization Factor}

According to Equation 1 the CF for Nueva Lagoon is $3.16 \times 10^{-1}$ with a standard error of $\pm 1.84 \times 10^{-}$ ${ }^{1} \mathrm{PAF} \cdot \mathrm{m}^{3} \cdot \mathrm{yr} \cdot \mathrm{m}^{-3}$, and a $95 \%$ confidence interval of $8.30 \mathrm{x} 10^{-2}-7.83 \times 10^{-1} \mathrm{PAF} \cdot \mathrm{m}^{3} \cdot \mathrm{yr} \cdot \mathrm{m}^{-3}$.

\section{Impact Score}

The impact score is calculated as a product of the characterization factor (CF) developed for Nueva Lagoon $\left(3.16 \mathrm{x} 10^{-1} \mathrm{PAF} \cdot \mathrm{m}^{3} \cdot \mathrm{yr} \cdot \mathrm{m}^{-3}\right)$ and the crop evapotranspiration (ET $\mathrm{Erop}_{\text {cop }}$ (Equation 10). Crop evapotranspiration was obtained from "Las Palmerillas" experimental station close to Albufera the Adra (constructed to improve the efficiency in agricultural production) ${ }^{30}$ and was converted to $\mathrm{m}^{3} \cdot \mathrm{yr}^{-1}$ taking into account the cultivation area from the study ${ }^{21}$ close to Adra. Table 3 shows the Impact Score $\left(\mathrm{m}^{3} \cdot \mathrm{PAF} \cdot \mathrm{yr}\right)$ for each crop per unit of area and per tonne of production $\left(\mathrm{m}^{3} \cdot \mathrm{PAF} \cdot \mathrm{tonne} \mathrm{e}^{-1} \cdot \mathrm{yr}\right)$ considering the local productions in that area. ${ }^{23}$

$$
I S=C F \cdot E T_{\text {crop }}
$$


Table 3: Characteristics and impact scores for the 8 main crops in the area of study: greenhouse area $\left(\mathbf{G H}_{\mathrm{Area}}\right)$, crop evapotranspiration (ET $\left.T_{\text {crop }}\right)$, impact score per area $\left(\mathbf{I S}_{1, \mathrm{per}}\right.$ area)and its assigned percentage $\left(\mathbf{I S}_{1, \%}\right)$, crop's yield $\left(\mathbf{Y}_{\mathrm{c}}\right)$ and $\mathbf{I m p a c t}$ Score per tonne $\left(\mathbf{I S}_{2, \text { tonne }}\right)$.

\begin{tabular}{lcc|cc|cc}
\hline \multicolumn{1}{c}{ Crops } & $\mathbf{G H}_{\text {Area }}$ & $\mathbf{E T}_{\text {crop }}$ & $\mathbf{I S}_{\mathbf{1}, \text { per area }}$ & $\mathbf{I S}_{\mathbf{1}, \%}$ & $\mathbf{Y}_{\mathbf{c}}$ & $\mathbf{I S}_{2, \text { tonne }}$ \\
\hline & $\mathrm{Ha}$ & $\mathrm{m}^{3} \cdot \mathrm{ha}^{-1}$ & $\mathrm{~m}^{3} \cdot \mathrm{PAF} \cdot \mathrm{yr}$ & $\%$ & tonne $\mathrm{ha}^{-1}$ & $\mathrm{~m}^{3} \cdot \mathrm{PAF} \cdot$ tonne $^{-1} \cdot \mathrm{yr}$ \\
\hline Tomato & 216.1 & $3.47 \times 10^{+03}$ & $7.49 \times 10^{+04}$ & 29.6 & 100.6 & $3.44 \times 10^{+00}$ \\
Pepper & 180.5 & $3.78 \times 10^{+03}$ & $6.81 \times 10^{+04}$ & 26.9 & 61.7 & $6.12 \times 10^{+00}$ \\
Cucumber & 95.1 & $1.61 \times 10^{+03}$ & $1.53 \times 10^{+04}$ & 6.0 & 87.0 & $1.85 \times 10^{+00}$ \\
Zucchini & 97.9 & $2.81 \times 10^{+03}$ & $2.75 \times 10^{+04}$ & 10.9 & 54.5 & $5.15 \times 10^{+00}$ \\
Watermelon & 101.1 & $1.79 \times 10^{+03}$ & $1.81 \times 10^{+04}$ & 7.1 & 69.6 & $2.57 \times 10^{+00}$ \\
Melon & 115.0 & $2.98 \times 10^{+03}$ & $3.42 \times 10^{+04}$ & 13.5 & 36.0 & $8.27 \times 10^{+00}$ \\
Aubergine & 33.7 & $2.84 \times 10^{+03}$ & $9.57 \times 10^{+03}$ & 3.8 & 72.6 & $3.91 \times 10^{+00}$ \\
Green bean & 59.7 & $8.69 \times 10^{+02}$ & $5.19 \times 10^{+03}$ & 2.1 & 15.3 & $5.68 \times 10^{+00}$ \\
\hline
\end{tabular}

For the cultivated area considered, tomato is the crop that shows the highest impact score, with approximately $30 \%$ of the overall impact, because tomato is the most produced crop in the province, whereas green bean shows the smallest impact with around $2 \%$ due to a relatively small cultivated area. However, when we consider the total impact score per tonne of production, we obtain different results due to different crop yields. The low yield of melon leads to the highest impact per tonne, while cucumber with a higher yield leads to the lowest impact score per tonne for the crops studied. ${ }^{22}$

Application in LCA studies. This work derived the first CF for salinity impacts in a coastal wetland defined as the change in the Potentially Affected Fraction (PAF) of species due to a change in salinity related to the extraction of groundwater for crop irrigation. This case study takes the expectation away that this is a fully applicable approach for the whole world and it proved to be very relevant indeed. The impacts on wetland biodiversity due to the irrigation of the existing crops close to the study area, were calculated using the proposed CF.

A comparison between the salinity impacts of the main crops tomato, cucumber, zucchini, melon and aubergine with other impact categories was carried out in order to investigate the relative importance 
345 protection "ecosystem quality" of the ReCiPe methodology ${ }^{54}$. Experimental data for these crops were 346 adapted from Stoessel et al. ${ }^{60}$ taking into account a local yield (Table 3) in Adra greenhouses. The 347 crop-specific impact scores presented in Table $3\left(\mathrm{PAF} \cdot \mathrm{m}^{3} \cdot \mathrm{yr} \cdot\right.$ tonne $\left.^{-1}\right)$ were converted into 348 species $\cdot \mathrm{yr} \cdot \mathrm{kg}^{-1}$ considering the recommended freshwater species density ${ }^{54}\left(7.89 \times 10^{-10} \mathrm{species} \cdot \mathrm{m}^{-3}\right)$ and 349 the conversion ${ }^{54} \mathrm{dPDF} / \mathrm{dPAF}=1$ (Table 4).

Table 4. Endpoint Impacts (species $\cdot \mathrm{yr} \cdot \mathrm{kg}^{-1}$ ) according to the ReCiPe methodology and the contribution of each category to the total ecosystem quality impact. No data was available for green beans and watermelon, and thus these crops are neglected in this comparison.

\begin{tabular}{|c|c|c|c|c|c|c|c|c|c|c|}
\hline Category impact & Tomato & & Cucumbe & & Zucchin & & Melon & & Aubergin & \\
\hline Unit & species $\cdot \mathrm{yr} \cdot \mathrm{kg}^{-1}$ & $\%$ & species $\cdot \mathrm{yr} \cdot \mathrm{kg}^{-1}$ & $\%$ & species $\cdot \mathrm{yr} \cdot \mathrm{kg}^{-1}$ & $\%$ & species $\cdot \mathrm{yr} \cdot \mathrm{kg}^{-1}$ & $\%$ & species $\cdot \mathrm{yr} \cdot \mathrm{kg}^{-1}$ & $\%$ \\
\hline $\begin{array}{l}\text { Salinity impact due to } \\
\text { water use }\end{array}$ & $2.72 \times 10-12$ & 0.31 & $1.46 \times 10-12$ & 0.18 & $4.06 \times 10-12$ & 0.08 & $6.53 \times 10-12$ & 0.35 & $3.09 \mathrm{E}-12$ & 0.02 \\
\hline Climate change & $6.16 \times 10-10$ & 69.6 & $5.85 \times 10-10$ & 73.1 & $1.96 \times 10-9$ & 37.4 & $7.07 \times 10-10$ & 38.2 & $3.67 \times 10-9$ & 70.4 \\
\hline Terrestrial acidification & $2.32 \times 10-12$ & 0.26 & $2.12 \times 10-12$ & 0.26 & $9.88 \times 10-12$ & 0.19 & $3.38 \times 10-12$ & 0.18 & $1.43 \times 10-11$ & 0.28 \\
\hline $\begin{array}{l}\text { Freshwater } \\
\text { eutrophication }\end{array}$ & $3.85 \times 10-13$ & 0.04 & $3.46 \times 10-13$ & 0.04 & $5.63 \times 10-13$ & 0.01 & $3.82 \times 10-13$ & 0.02 & $2.56 \times 10-12$ & 0.05 \\
\hline Terrestrial ecotoxicity & $2.40 \times 10-11$ & 2.70 & $2.10 \times 10-12$ & 0.26 & $4.73 \times 10-12$ & 0.09 & $3.08 \times 10-12$ & 0.17 & $7.38 \times 10-11$ & 1.42 \\
\hline Freshwater ecotoxicity & $2.59 \times 10-14$ & 0.00 & $1.10 \times 10-14$ & 0.00 & $1.39 \times 10-13$ & 0.00 & $7.65 \times 10-14$ & 0.00 & $1.14 \times 10-13$ & 0.00 \\
\hline Marine ecotoxicity & $1.21 \times 10-16$ & 0.00 & $4.86 \times 10-17$ & 0.00 & $1.86 \times 10-16$ & 0.00 & $8.28 \times 10-17$ & 0.00 & $5.33 \times 10-16$ & 0.00 \\
\hline $\begin{array}{l}\text { Agricultural land } \\
\text { occupation }\end{array}$ & $2.15 \times 10-10$ & 24.3 & $1.82 \times 10-10$ & 22.7 & $3.12 \times 10-09$ & 59.5 & $1.08 \times 10-9$ & 58.4 & $1.25 \times 10-9$ & 24.1 \\
\hline Urban land occupation & $8.11 \times 10-12$ & 0.91 & $1.29 \times 10-11$ & 1.61 & $4.48 \times 10-11$ & 0.86 & $2.18 \mathrm{E} \times 10-11$ & 1.18 & $7.62 \times 10-11$ & 1.46 \\
\hline $\begin{array}{l}\text { Natural land } \\
\text { transformation }\end{array}$ & $1.68 \times 10-11$ & 1.90 & $1.52 \times 10-11$ & 1.89 & $9.87 \times 10-11$ & 1.88 & $2.72 \times 10-11$ & 1.47 & $1.20 \times 10-10$ & 2.30 \\
\hline Total & $8.84 \times 10^{-10}$ & 100 & $7.99 \times 10^{-10}$ & 100 & $5.24 \times 10^{-9}$ & 100 & $1.84 \times 10^{-9}$ & 100 & $5.21 \times 10^{-9}$ & 100 \\
\hline
\end{tabular}

354 The results for all crops show that, if the generic freshwater species density from ReCiPe is used 355 (Table 4), the impact of salinity (due to water use) for the total damage to ecosystems is in the range of 356 terrestial acidification for tomato $\left(2.72 \times 10^{-12}\right.$ species $\left.\cdot \mathrm{yr}^{\mathrm{kg}} \mathrm{kg}^{-1}\right)$, cucumber $\left(1.46 \times 10^{-12} \mathrm{species} \cdot \mathrm{yr}^{\mathrm{kg}} \mathrm{kg}^{-1}\right)$ 357 and melon $\left(6.53 \times 10^{-12}\right.$ species $\left.\cdot \mathrm{yr}^{\mathrm{k}} \mathrm{kg}{ }^{-1}\right)$, in the range of terrestial ecotoxicity for zucchini $\left(4.06 \times 10^{-12}\right.$ 358 species $\left.\cdot \mathrm{yr}^{\mathrm{kg}} \mathrm{kg}^{-1}\right)$ and in the range of freshwater eutrophication aubergine $\left(3.09 \times 10^{-12} \mathrm{species} \cdot \mathrm{yr}^{\mathrm{k}} \cdot \mathrm{kg}^{-1}\right)$. 359 The relative contribution to the total impact score is dominated by climate change for all the crops with 360 approximately $70 \%$ in tomato, cucumber and aubergine and around $40 \%$ in zucchini and melon. The 
climate change ecosystems impact category considers fertilizing (ammonium nitrate, single superphosphate and potassium sulphate) and electricity consumption for the irrigation system, which is the highest contributing impact when capital goods are not considered.

Note that if a specific freshwater species density $\left(9.47 \times 10^{-5}\right.$ species $\left.\cdot \mathrm{m}^{-3}\right)$ from the wetland had been used instead of generic freshwater species density from ReCiPe, the salinity impact for the total damage to ecosystems would represent in all studied crops the major contribution (98-99\%) between all categories impact (tomato $3.26 \times 10^{-07}$ species.yr $\cdot \mathrm{kg}^{-1}$, cucumber $1.75 \times 10^{-07}$ species.yr $\cdot \mathrm{kg}^{-1}$, zucchini

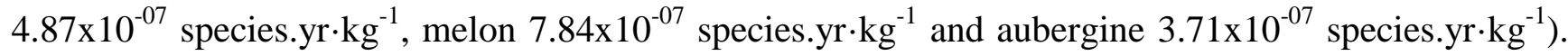
Hence, the difference between them shows that taking a global average value can be misleading since local species richness can be very different.

Outlook. Future efforts should be undertaken in order to further methodological development and make global characterization factors available. It is a broader approach (exploratory case study) with a more global perspective shall be developed. This will close an important gap in the LCIA methodology regarding the relevant impacts on coastal wetlands.

In this work we used the freshwater species density from the ReCiPe model, acknowledging that freshwater species density can greatly vary depending on local conditions (e.g. the freshwater species density in Albufera de Adra is $9.47 \times 10^{-5}$ species $\cdot \mathrm{m}^{-3}$ ). Hence, further improvements in LCIA endpoint methodologies could be considered given that species density for freshwater was shown to be higher than terrestrial species density ${ }^{61}$, in contrast to estimates proposed by ReCiPe.

Acknowledgements. The authors thank Miguel Rodríguez from Universidad Pablo de Olavide (Sevilla-Spain) and Mariano Paracuellos from Universidad de Almería (Almería-Spain) to provide us with specific data and pictures for Albufera de Adra and explanations about the current situation regarding the last decades.

The research was funded by AGAUR Research Grant 2011BE-DGR-385 by the Catalan Government (Spain) and by the European Commission under the $7^{\text {th }}$ framework program on environment 
better sustainability assessment of technologies.

Supporting information. Details on the fate and effect factor and further results are available free of charge via the Internet at http://pubs.acs.org.

\section{Literature cited}

1. FAO, AQUASTAT database. In 2006.

2. Hollis, G. E., The causes of wetland loss and degradation in the Mediterranean. 1992; p pp. 83-90.

3. OECD/IUCN Guidelines for aid agencies for improved conservation and sustainable use of tropical and sub-tropical wetlands; Paris, France, OECD: 1996.

4. Rodríguez-Rodríguez, M.; Benavente, J.; Alcalá, F.; Paracuellos, M., Long-term water monitoring in two Mediterranean lagoons as an indicator of land-use changes and intense precipitation events (Adra, Southeastern Spain). Estuarine Coastal and Shelf Science 2011, 91, (3), 400-410.

5. Agardy, T.; Alder, J., Coastal Systems. Millennium Ecosystem Assessment, Ecosystems and Human Well-Being: Current State and Trends Island Press: Washington, DC, 2005, 1, 513-549.

6. Jolly, I.; McEwan, K.; Holland, K., A review of groundwater-surface water interactions in arid/semi-arid wetlands and the consequences of salinity for wetland ecology. Ecohydrology 2008, 1, (1), 43-58.

7. The Ramsar Conventional on Wetlands. 1971.

8. Molden, D.; Vithanage, M.; de Fraiture, C.; Faures, J.; Gordon, L.; Molle, F.; Peden, D., Water Availability and Its Use in Agriculture. Elsevier B.V. 2011.

9. International Organization for Standardization (ISO), 14040 - Environmental management - Life cycle assessment - Principles and framework. In Geneva, 2006.

10. European commission, Joint Research Centre and Institute for Environment and Sustainability. ILCD Handbook. International Reference Life Cycle Data System. Framework and requirements for Life Cycle Impact Assessment models and indicators. 2010.

11. Pfister, S.; Koehler, A.; Hellweg, S., Assessing the Environmental Impacts of Freshwater Consumption in LCA. Environmental Science \& Technology 2009, 43, (11), 4098-4104.

12. van Zelm, R.; Schipper, A.; Rombouts, M.; Snepvangers, J.; Huijbregts, M., Implementing Groundwater Extraction in Life Cycle Impact Assessment: Characterization Factors Based on Plant Species Richness for the Netherlands. Environmental Science \& Technology 2010, 45, (2), 629-635.

13. Hanafiah, M.; Xenopoulos, M. A.; Pfister, S.; Leuven, R.; Huijbregts, M., Characterization Factors for Water Consumption and Greenhouse Gas Emissions Based on Freshwater Fish Species Extinction. Environmental Science \& Technology 2011, 45, (12), 5272-5278.

14. Verbrugge, L. H.; Schipper, A.; Huijbregts, M. J.; Van der Velde, G.; Leuven, R. E. W., Sensitivity of native and non-native mollusc species to changing river water temperature and salinity. Biol Invasions 2012, 14, (6), 1187-1199.

15. Verones, F.; Bartl, K.; Pfister, S.; Jiménez Vílchez, R.; Hellweg, S., Modeling the Local Biodiversity Impacts of Agricultural Water Use: Case Study of a Wetland in the Coastal Arid Area of Peru. Environmental Science \& Technology 2012, 46, (9), 4966-4974.

16. Molina Vázquez, F., Ficha Informativa de los Humedales de Ramsar (FIR). In Consejería de Medio Ambiente de la Junta de Andalucía (España), 2006.

17. Pennington, D. W.; Payet, J.; Hauschild, M., Aquatic ecotoxicological indicators in life-cycle assessment. Environmental Toxicology and Chemistry 2004, 23, (7), 1796-1807.

18. Paracuellos, M., How does the semiarid wetlands of the Iberian Peninsula evolve? The case of the Almería province (Spanish). Oxyura 2009, 12, (1), 25-39.

19. Rodríguez-Rodríguez, M., Hydrogeology of ponds, pools, and playa-lakes of southern Spain. Wetlands 2007, 27, (4), 819-830.

20. Slinger, D.; Tension, K., Salinity Glove Box Guide for NSW Murray \& Murrumbidgee. In Industries, N. D. o. P., Ed. 2005. 
21. Fernández, C.; Pérez, J.; , Caracterización de los invernaderos de la provincia de Almería. Cajamar 2004.

22. Junta; Andalucía, Anuario de la agricultura almeriense. In La Voz de Almería, 2011.

23. Andalucia, J. d., Anuario de estadísticas agrarias y pesqueras de Andalucía. In 2012.

24. Tolón Becerra, A.; Lastra Bravo, X., La agricultura intensiva del poniente almeriense. Diagnóstico e instrumentos de gestión ambiental. M+A. Revista Electrónic@ de Medio Ambiente 2010, 8, 18-40.

25. Google, Earth Database v 6.2. In 2012.

26. Palisade, @RISK Version 5.0. . In 2012.

27. Cespedes, A. J.; García, M. C.; JJ., P.; Cuadrado, I. M., Caracterización de la explotación hortícola almeriense. In Fiapa y Fundación Cajamar, 2009.

28. Pulido, A.; Morales, G.; Benavente, J., Hidrogeology of the Adra River delta (spanish). Estudios Geológicos 1988, 44, 429-443.

29. IFAPA EI Instituto Andaluz de Investigación y Formación Agraria, Pesquera, Alimentaria y de la Producción Ecológica http://www.juntadeandalucia.es/agriculturaypesca/ifapa/web

30. Fernández, M.; Orgaz, F.; Fereres, E.; López, J. C.; Céspedes, A.; Pérez, J.; Bonachela, S.; Gallardo, M., Programación del riego de cultivos hortícolas bajo invernadero en el sudeste español. In CAJA MAR (Caja Rural de Almería y Málaga): 2001.

31. GAMS, GAMS Development Corporation, Washington, DC, USA. 2012.

32. Glenn, E.; Thompson, T.; Frye, R.; Riley, J.; Baumgartner, D., Effects of salinity on growth and evapotranspiration of Typha domingensis Pers. Aquatic Botany 1995, 52, (1-2), 75-91.

33. Ahmed, H. B.; Ammar, D. B.; Zid, E., Physiology of salt tolerance in Atriplex halimus L. In Biosaline Agriculture and High Salinity Tolerance, Abdelly, C.; Öztürk, M.; Ashraf, M.; Grignon, C., Eds. Birkhäuser Basel: 2008; pp 107-114.

34. Mufarrege, M.; Di Luca, G.; Hadad, H.; Maine, M., Adaptability of Typha domingensis to high pH and salinity. Ecotoxicology 2011, 20, (2), 457-465.

35. Van Wijk, R.; Van Goor, E.; Verkley, J., Ecological studies on Potamogeton pectinatus L. II. Autecological characteristics, with emphasis on salt tolerance, intraspecific variation and isoenzyme patterns. Aquatic Botany 1988, 32, (3), 239-260.

36. Calheiros, C. S. C.; Silva, G.; Quitério, P. V. B.; Crispim, L. F. C.; Brix, H.; Moura, S. C.; Castro, P. M. L., Toxicity of High Salinity Tannery Wastewater and Effects on Constructed Wetland Plants. International Journal of Phytoremediation 2011, 14, (7), 669-680.

37. Espinar, J.; García, L.; Clemente, L., Seed storage conditions change the germination pattern of clonal growth plants in Mediterranean salt marshes. American Journal of Botany 2005, 92, (7), 1094-1101.

38. Cambrollé, J.; Mateos-Naranjo, E.; Redondo-Gómez, S.; Luque, T.; Figueroa, M. E., Growth, reproductive and photosynthetic responses to copper in the yellow-horned poppy, Glaucium flavum Crantz. Environmental and Experimental Botany 2011, 71, (1), 57-64.

39. Lissner, J.; Schierup, H., Effects of salinity on the growth of Phragmites australis. Aquatic Botany 1997, $55,(4), 247-260$.

40. Lilleb $\varnothing$, A.; Pardal, M.; Neto, J.; Marques, J., Salinity as the major factor affecting Scirpus maritimus annual dynamics: Evidence from field data and greenhouse experiment. Aquatic Botany 2003, 77, (2), 111-120. 41. Bartolomé, M.; D’ors, A.; Sánchez-Fortún, S., Toxic effects induced by salt stress on selected freshwater prokaryotic and eukaryotic microalgal species. Ecotoxicology 2009, 18, (2), 174-179.

42. Hutchinson, I., Salinity Tolerance of plants of estuarine wetlands and associated uplands.

43. Guma, I. R.; Padrón-Mederos, M. A.; Santos-Guerra, A.; Reyes-Betancort, J. A., Effect of temperature and salinity on germination of Salsola vermiculata L. (Chenopodiaceae) from Canary Islands. Journal of Arid Environments 2010, 74, (6), 708-711.

44. Wang, J.-Q.; Lui, H.; Po, H.; Fan, L., Influence of salinity on food consumption, growth and energy conversion efficiency of common carp (Cyprinus carpio) fingerlings. Aquaculture 1997, 148, (2-3), 115-124.

45. Barman, U. K.; Jana, S. N.; Garg, S. K.; Bhatnagar, A.; Arasu, A. R. T., Effect of inland water salinity on growth, feed conversion efficiency and intestinal enzyme activity in growing grey mullet, Mugil cephalus (Linn.): Field and laboratory studies. Aquaculture International 2005, 13, (3), 241-256.

46. Bright, D. A.; Addison, J. Derivation of Matrix Soil Standards for Salt under the British Columbia Contaminated Sites Regulation.; 2002. 
47. Greenwood, M., Predicting the effects of salinity on three dominant macrophytes: An anticipatory approach to the restoration of degraded coastal wetlands in NSW, Australia. In.

48. Schuytema, G. S.; Nebeker, A. V.; Stutzman, T. W., Salinity Tolerance of \&lt;i\&gt;Daphnia magna and Potential Use for Estuarine Sediment Toxicity Tests. Archives of Environmental Contamination and Toxicology 1997, 33, (2), 194-198.

49. Payet, Y., Assessing toxic impacts on aquatic ecosystems in Life Cycle Assessment (LCA). Doctoral Thesis. École Polytechnique Fédérale de Lausanne 2004.

50. van de Meent, D.; Huijbregts, M. A. J., Calculating life-cycle assessment effect factors from potentially affected fraction-based ecotoxicological response functions. Environmental Toxicology and Chemistry 2005, $24,(6), 1573-1578$.

51. Verones, F.; Hanafiah, M. M.; Pfister, S.; Huijbregts, M. A. J.; Pelletier, G. J.; Koehler, A., Characterization Factors for Thermal Pollution in Freshwater Aquatic Environments. Environmental Science \& Technology 2010, 44, (24), 9364-9369.

52. Struijs, J.; De Zwart, D.; Posthuma, L.; Leuven, R. S. E. W.; Huijbregts, M. A. J., Field sensitivity distribution of macroinvertebrates for phosphorus in inland waters. Integrated Environmental Assessment and Management 2011, 7, (2), 280-286.

53. Rosenbaum, R.; Bachmann, T.; Gold, L.; Huijbregts, M.; Jolliet, O.; Juraske, R.; Koehler, A.; Larsen, H.; MacLeod, M.; Margni, M.; McKone, T.; Payet, J.; Schuhmacher, M.; Meent, D.; Hauschild, M., USEtox-the UNEP-SETAC toxicity model: recommended characterisation factors for human toxicity and freshwater ecotoxicity in life cycle impact assessment. The International Journal of Life Cycle Assessment 2008, 13, (7), 532-546.

54. Goedkoop, M.; Heijungs, R.; Huijbregts, M.; De Schryver, A.; Struijs, J.; van Zelm, R., ReCiPe 2008. A life cycle impact assessment method which comprises harmonised category indicators at the midpoint and the endpoint level.

2009.

55. Alcalá, F. J.; Solé, A.; Creus, C.; Domingo, F., Urban groundwater contribution to regional water bodies and groundwater dependent ecosystems. Case of the seaside town of Adra (SE Spain) (spanish). López-Geta, J. (Ed.), VII Simposio del Agua en Andalucía, Seville (Spain) 2008., 699-708.

56. Rodríguez-Rodríguez, M.; Benavente, J.; Moral, F., Hydrological regime and physical limnology in the lagoons of Adra (Almería, Spain) (spanish). In: VIII Simposio de Hidrogeología, Zaragoza (Spain),. In 2004; pp 409-419.

57. Waste.ideal.es (Magazine on line) http://waste.ideal.es/albuferadeadra.htm (01/07/2012),

58. Losa, T. M.; S., R. G., Estudio florístico y geobotánico de la provincia de Almería. . Archivos Instituto Aclimatación de Almería. 13 (1), 5-111.

59. R., S. Flora de Almería. Plantas vasculares de la provincia.; 1987.

60. Stoessel, F.; Juraske, R.; Pfister, S.; Hellweg, S., Life Cycle Inventory and Carbon and Water FoodPrint of Fruits and Vegetables: Application to a Swiss Retailer. Environmental Science \& Technology 2012, 46, (6), 32533262.

61. Vörösmarty, C. J.; Mclntyre, P. B.; Gessner, M. O.; Dudgeon, D.; Prusevich, A.; Green, P.; Glidden, S.; Bunn, S. E.; Sullivan, C. A.; C., R. L.; M., D. P., Global threats to human water security and river biodiversity. Nature . 2010, 467: 555-561. 